\title{
The Effect of Indyer as a Means of Communication Among the Tiv People of Vandeikya Local Government Area of Benue State, Nigeria
}

\author{
Nancy Ngunan Ugbagir ${ }^{1}$, Tim Cuttings Agber ${ }^{2}$ \\ ${ }^{1}$ Serial Section, University Library, Benue State University, Makurdi, Nigeria \\ ${ }^{2}$ Department of Research and Publication, Time Xperts Research Consults, Abuja, Nigeria \\ Email address: \\ ngunanugbagir@gmail.com (N. N. Ugbagir), timcuttingss@gmail.com (T. C. Agber)
}

\section{To cite this article:}

Nancy Ngunan Ugbagir, Tim Cuttings Agber. The Effect of Indyer as a Means of Communication Among the Tiv People of Vandeikya Local Government Area of Benue State, Nigeria. Humanities and Social Sciences. Vol. 3, No. 6, 2015, pp. 299-306. doi: $10.11648 /$ j.hss. 20150306.13

\begin{abstract}
Communication used to form a crucial part of the constituents of social administration of the Tiv society. The Tiv communication as a means of passing information or knowledge from one person or a group of persons to another through the Tiv language, music, dance, symbols and signs was predicated chiefly upon the Tiv indigenous Religious canon. Communication was and is still one of the important aspects of the Tiv social setting among the Kunav Mega Clan of the Tiv people who used different ways to pass information from one entity to another among the populace. Consequently, due to the importance of communication to the people, technological innovations were drastically improved to invent better means or devices of communication and Indyer was invented from the earlier Gbagede and Ilyu. The Indyer was paramount among different means of communication among the Tiv people of Vandeikya and as such any message coming from the beating of Indyer (Indyer í Tan or Kuhan) was considered with grave seriousness. The study looks at the effect of Indyer as a means of communication among the Tiv people of Vandeikya local government area of Benue state, Nigeria. A sample of 363 Tiv people of Vandeikya was drawn using random sampling technique. Apparently, mean and standard deviation were used in answering the research questions while Chi-Square was used in testing the hypotheses at 0.05 level of significance. The study discovered that Indyer has significant effect as a mean of communication among the Tiv people of Vandeikya Local Government Area of Benue State, Nigeria however, there are potential challenges affecting it. It was recommended that the Federal Government of Nigeria should discard the International Intellectual Property Laws such as The Paris Convention and the Agreement on TradeRelated Aspects of Intellectual Property (TRIPs) and develop its IP laws to be in conformity with indigenous practices and what is obtainable in the Nigerian folds and Christian converts and leaders should accept Indyer as a technological device not a fetish component.
\end{abstract}

Keywords: Indyer, Tiv People, Vandeikya, Indigenous Communication Modes

\section{Introduction}

Communication used to form a crucial part of the constituents of social administration of the Tiv society. The Tiv communication as a means of passing information or knowledge from one person or a group of persons to another through the Tiv language, music, dance, symbols and signs was predicated chiefly upon the Tiv indigenous Religious canon. Apparently, the Tiv people of Vandeikya like other parts of Tiv land had various ways of passing information across to their populace for safety, admonition, administration or control and entertainment. Communication was done through gunshots, town criers and importantly, the Indyer. Indyer is a Tiv indigenous ritual slit wooden hollow $\log$ instrument for communication, whose sound can be heard over a distance of about 30 kilometers made of Yiase (Counter wood or African mahogany).

Communication is extremely pivotal to human development. Poor communication or a lack of it, impacts negatively on development. Communication has some of its functions as offering opportunity for informed choices, increasing information access to people and encouraging dialogue among leaders and followers. It is both an organic 
part of development and an instrument for furthering development. Essentially, communication serves as a liberating tool that allows a people to champion their own development agenda (Diaz-Bordenave, 1979, Freire, 1985, Hoffmann, 2000 \& Ayirebasia, 2008).

Apparently, for the purposes of development, mutual coexistence, security and advancement of frontiers of knowledge among others, the Tiv people developed their different indigenous modes or ways of communication like other African peoples and aboriginal folks of the world. These indigenous modes of communication among the Tiv people particularly from Vandeikya included gunshots, bush burning, animal horns, Ilyu and the Indyer. Messages, instructions of information coming from the Indyer were valued with grave solemnity due to the fact that the Indyer wooden slit ritual drum was an appendage of the Tiv indigenous religion that was the life of the Tiv people.

Consequently, despite the importance of the Indyer as a means of communication among the Tiv people of Vandeikya, the advent of Christianity and the inversion of the British colonialists worked tirelessly to thwart the use and development of this communication device among the people. It is therefore necessary to investigate the effect of Indyer as a means of communication and challenges facing its use or development among the Tiv people of Vandeikya Local Government Area of Benue State, Nigeria.

\section{Statement of the Problem}

Communication was and is still one of the important aspects of the Tiv social setting among the Kunav Mega Clan of the Tiv people who used different ways to pass information from one entity to another among the populace. Consequently, due to the importance of communication to the people, technological innovations were drastically improved to invent better means or devices of communication and Indyer was invented from the earlier Gbagede and Ilyu. The Indyer was paramount among different means of communication among the Tiv people of Vandeikya and as such any message coming from the beating of Indyer (Indyer $i$ Tan or Kuhan) was considered with grave seriousness. However, the advent of Christianity in Tiv land in 1911 waged war against this vital indigenous device for communication and despite the efforts of Tiv Traditional Priests, Researchers and Tiv Indigenous Technologists to rekindle this practice, the Indyer is almost extinct. Christianity forced the people to believe that their different indigenous means of communication were aberrant and mundane thereby enticing them to derail from the practice and the western colonial masters also failed to teach the people how to make the western communication devices themselves. As a result, the essence of communication among the Tiv people of Vandeikya seems to be abated. Essentially, this can constitute a hazardous technological retrogression, moral decadence and maladministration of the Tiv society in the near future if this is allowed to continue hence this study seeks to investigate the effect of Indyer as a means of communication among the Tiv people of Vandeikya Local Government of Benue State.

\subsection{Purpose of the Study}

The purpose of this study is to investigate the impact of Indyer as a means of communication among the Tiv people of Vandeikya Local Government Area of Benue State. Specifically, the study seeks to:

1. Identify areas Indyer was used as a means of communication among the Tiv people of Vandeikya Local Government Area of Benue State.

2. Find out the effect of Indyer as a means of communication among the Tiv people of Vandeikya Local Government Area of Benue State.

3. Determine challenges of Indyer as a means of communication among the Tiv people of Vandeikya Local Government Area of Benue State.

\subsection{Research Questions}

1. What are the areas Indyer was used as a means of communication among the Tiv people of Vandeikya Local Government Area of Benue State?

2. What are the effects of Indyer as a means of communication among the Tiv people of Vandeikya Local Government Area of Benue State?

3. What are the challenges affecting Indyer as a means of communication among the Tiv people of Vandeikya Local Government Area of Benue State?

\subsection{Research Hypotheses}

1. There are no significant effects of Indyer as a means of communication among the Tiv people of Vandeikya Local Government Area of Benue State, Nigeria.

2. There are no significant challenges affecting Indyer as a means of communication among the Tiv people of Vandeikya Local Government Area of Benue State, Nigeria.

\section{Literature Review}

\subsection{The Tiv People of Vandeikya}

The Tiv people, wherever they may be found in the world, are people who share a common ancestry or genealogy, language and general cultural values or norms (Agber, Ugbagir, Mngutyô \& Amaakaven, 2014). This therefore, suggests that the Tiv people of Vandeikya have the same ancestry or genealogy, language and general culture values or norms with the other Tiv people wherever they are found globally. The Tiv people of Vandeikya are known to be the Kunav people. Kunav is a mega clan of the Tiv from what is known as Jerchira. The Vandeikya people are located in a geographical entity known as Vandeikya Local Government Area of Benue State in Nigeria.

Vandeikya Local Government is located between longitude $8^{\circ} 30^{\prime}$ to $9^{\circ} 00^{\prime}$ East and latitude $6^{\circ} 30^{\prime}-7^{\circ} 00^{\prime}$ North (Agera, 
Adegeye \& Jimoh, 2009; Agber \& Mase, 2014). The local government is made up of twelve administrative wards namely-Mbaityough, Mbakaange, Mbayongo, Ningev, and Nyumangbagh (making up Tyev Development Area). Other wards include: Mbadede, Mbagbam, Mbagbera, Mbajor, Mbakyaha, and Tsambe (making up Kyan Development Area).Vandeikya Township Ward carved from Mbagbera Mbakaange and Ningev Wards is the VLG headquarters (Agera, Adegeye \& Jimoh, 2009).

More so, Vandeikya Local Government Area has a population of 234,567 (National Population Commission, 2009) and the local government shares boundaries with Obudu and Bekwara in Cross River State to the East, Ushongo to the North and Konshisha LGA to the West (Agber \& Mase, 2014; Wikipedia, 2014).

\subsection{Communication}

Rapid growth and expansion of communication technologies in recent years have led to the glorification of change and have discounted and underplayed the continuity of the past and present. The focal point of research is how modern media change or replace old ways of thinking, behaving, or communicating. However, some elements of the old system remain and continue to play a vital role in communication in many regions of the world today. The implications of this continuity to development are not fully explored (Wang \& Dissanayake, 1984).

Mundy and Compton (1991) asserted that indigenous communication has value in its own right. It is an important aspect of culture and it is the means by which a culture is preserved, handed down and adapted. But indigenous communication is being eroded by exogenous systems - the mass media, schools, agricultural extension, and bureaucracies - endangering the survival of much valuable information.

Centuries before the colonial era in Africa and elsewhere, communities depended on their own indigenous modes of communication. Of late, however, these modes of communication are in mutation. In some cases, they face extinction. Western culture has introduced modem modes of communication - Print, Radio, TV, and the Internet. International organizations such as UNESCO record measurements of various aspects of communication in favor of the technologically-based communication systems. Indigenous modes of communication are, thus, marginalized (AnsuKyeremeh, 1997 \& Ayirebasia, 2008).

The term and concept communication has been defined in different perspectives by researchers based on the angle from which it is defined. Ashalatha (2015) defined communication as the process of exchanging messages or information between two or more parties. It is sharing our feelings, ideas and opinions with others. This can be intellectual, personal, spoken or written in nature. We live in groups and man is invariably a social animal. As the social needs insist that we share our thoughts with others. This can be called communication. It is a two-way process. In spoken communication, we have speakers and listeners who send and receive verbal messages from each other. In written communication, we have writers and readers, whereas in visualization and observation, the symbols and signs are included.

\subsection{Indigenous Communication Modes of the Tiv People of Vandeikya}

Indigenous communication of the Tiv people refers to traditional ways of transmitting ideas or knowledge by Tiv language, sound or symbols from one person to another or from one group of persons to another. The Tiv people communicated to themselves, ancestral spirits, the azôv spirits and the gods. Essentially, indigenous communication was efficiently and effectively done through different media among the Tiv people such as gunshots and town criers.

The town criers were used to summon elders or age groups in the society to assemble at the village square for some social or political activities. The town crier had some unique messages which not many people could understand their meanings, except the indigenes of the societies concerned. Gunshots have a wider coverage more than town criers and were used to announce the death of very important political and religious leaders in African societies. They were also use to announce the final truanting of new rulers, remind the people of an impending danger and summoning emergency meeting to take urgent decisions on issues demanding immediate attention in African traditional society. Among the Tiv, Idoma and Jukun, for example, gunshots played political, religious and social functions of announcing the completion of final burial formalities of every important or elderly person in the society (Beltran, 1974, Finnegan, 1979 \& Ushe, 2010).

Moreover, other modes or media of communication among the Tiv people of Vandeikya Local Government Area of Benue state included tying of nuts (Atsur á Tan or Ichur $i$ Tan), whistling (Hondu Tungwan), Animal Horn (Korugh), Pipe (Imyar) and above all the Indyer Slit Wooden Drum (Indyer).

\subsection{The Tiv Indyer}

The Indyer as a Tiv indigenous ritual slit wooden hollow $\log$ instrument for communication used to be the most potent communication device in the Tiv fold including the Vandeikya people. Apparently, ownership of Indyer was vested in the hands of Agnate Kinsfolk (Ityo) and Matrilineal Kinsfolk (Igbya) and owners of Indyer were noble men in the Tiv society and communicant members of the Tiv indigenous religion. Anyone desiring ownership of Indyer was required to inform the Ityo and Igba to get permission; after which he consulted the Indyer Engineer (Orgban Indyer) to make the Indyer for him.

Oral history has it that Indyer required series of blood sacrifices for its making. The blood needed for sacrifice for the making of the Indyer was that of the humans and Tiv cow (Bua Tiv). Moreover, whatever costs were involved in the Indyer making, it was a potent tool for communication among the Tiv people of Vandeikya (Mela, 2015 in a verbal discussion with Nancy Ugbagir and Tim Cuttings). 
In spite of the devastating effect of westernization on Tiv cultural heritage, the trinity of Tiv religion and eschatology continues to be the potential factor and a living institution of the votaries. The Tiv still belief in Kumun $u$ tamen as the home of the ancestors. Ilu and Indyer wooden drums are still used in communicating to the ancestral world (Gbenda, 2005).

Waya (as cited in Ahamefula, Okoye, Onwuegbuchunam \& Uzoigwe, 2014) noted that in the Tiv culture, Indyer instrument can be to announce deaths or vital events in Tiv culture. The sounds produced communicate a particular meaning tied to a particular event. For instance, announcing the death of a prominent or illustrious son. The Indyer sound announces the circumstances surrounding the death and also the name of the person. Again, messages can also be sent to ask people to gather or not to gather. Also the Indyer sound can send messages to the women folk to go in doors. The Indyer sound can also be sounded to announce meetings, new yam festivals, first rain, and also the arrival of new babies. The Indyer in the Tiv cultural communication is akin to the modern day mass communication gadget.

More so, among the Tiv of Vandeikya Indyer, which Ushe (2015) describe as the talking drums is the traditional method of communication that was used to formalize announcements about impending danger, birth, deaths, marriages, forthcoming hunts or wrestling matches.

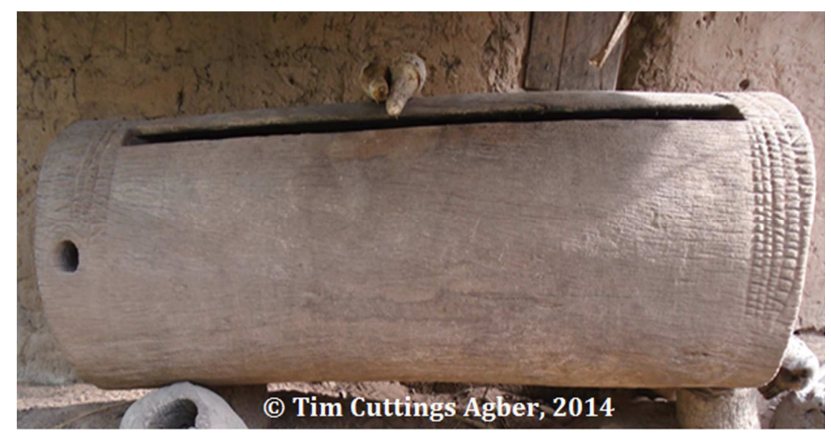

Figure 1. Indyer Slit Wooden Drum - Used here under the express permission of Tim Cuttings.

\section{Methodology}

The study adopted a public opinion survey design. This is a type of design that allows the researcher to - collect data from or - find the opinions of people in a given area towards an issue or event that is of interest to the generality of the populace in an area that might be as large as a country or as small as a town or even university campus.

\subsection{Population and Sample}

The target population of this study was Tiv people of Vandeikya Local Governments Area of Benue State. The National Population Commission (2009) puts the population of Vandeikya at 234,567. A sample of 363 was therefore, drawn using a sample size table, (Emaikwu, 2015). Random sampling technique was used in selecting the sample of the study.

\subsection{Instrument for Data Collection}

The instrument used for data collection was the Effect of Indyer as a Means of Communication Questionnaire (EIMCQ) constructed by the researchers. Section A of the questionnaire was on bio-data of the respondents covering council ward, occupation, sex and age. Section B consisted of 6 variables of Areas Indyer was used as a Means of Communication among the Tiv people of Vandeikya Local Government Area. Section C consisted of 4 variables of Effects of Indyer as a Means of Communication among the Tiv People of Vandeikya and Section D consisted of 6 variables of Challenges of Indyer as a Means of Communication among the Tiv People of Vandeikya. Apparently, the 16 item questionnaire adapted a 4 point rating scale and respondents were asked to respond by ticking the applicable responses (SA) strongly agree, (A) agree, (D) disagree and (SD) strongly disagree. The analysis used mean and standard deviation. Any item of the instrument whose mean rating scores was 2.50 and above was considered significant and any item less than 2.50 was considered not significant.

The questionnaires were administered to the respondents in the study area and were retrieved from the respondents by the researchers and four (4) trained research assistants. During the administration of the questionnaires, the researchers with their trained research assistants read the questionnaire and interpreted them in Tiv language to respondents who cannot read and write, and the options they selected were ticked for them. The questionnaires were administered and retrieved through personal contact, which Agber, Udu, Fiase and Aniho (2015) believe is appropriate for avoiding extraneous effect and traits that might have distorted the independent variable effect on the dependent variables.

\subsection{Answers to Research Question}

The data for this research were collected using 4-point rating scale instrument and on each of the research questions, data were collected on related items in the instrument. Consequently, the data collected were analyzed using mean and standard deviation. Items of the instrument with mean rating scores of 2.50 and above were deemed significant and items with less were not considered significant.

\subsection{Demographic Information}

Demographically, data were collected from 363 Tiv people of Vandeikya Local Government Area of Benue State out of which 297 were male representing $81.8 \%$ while 66 representing $18.24 \%$ were female. On respondents' Council Ward, 26 representing $6.30 \%$ were from Mbadede, 30 representing $8.30 \%$ were from Mbagbam, 26 representing $7.20 \%$ were from Mbakaange, 14 representing 3.90\% were from Mbakyaha, 20 representing $5.50 \%$ were from Mbatyough, 71 representing 19.60\% were from Mbayongo, 27 representing $7.40 \%$ were from Ningev, 45 representing $12.40 \%$ were from Nyumangbagh, 18 representing $5.00 \%$ 
were from Tsambe, 35 representing 9.60\% were from Vandeikya Township I and 27 representing 7.40\% were from Vandeikya Township II. On their occupation, 176 representing 48.50 were Civil Servants, 118 representing $32.50 \%$ were Farmers and 69 representing 19.00\% were Traditional Priests and on their age 28 representing $7.70 \%$ aged 30-49 years, 297 representing 81.8\% aged 50-69 years and 38 representing $10.50 \%$ aged 70 years above.
What are the areas Indyer was used as a means of communication among the Tiv people of Vandeikya Local Government Area of Benue State?

In order to answer Research Question 1, data were collected on areas Indyer was used as a means of communication among the Tiv people of Vandeikya Local Government Area of Benue State, analyzed and presented in Table 1.

\subsection{Research Question 1}

Table 1. Descriptive Statistics of Areas Indyer was used as a Means of Communication among the Tiv People of Vandeikya Local Government Area of Benue State, Nigeria.

\begin{tabular}{|c|c|c|c|}
\hline \multicolumn{4}{|l|}{ Descriptive Statistics } \\
\hline & $\mathbf{N}$ & Mean & Std. Deviation \\
\hline $\begin{array}{l}\text { Indyer was used for announcing the advancing of enemies and asking warriors (Anomaior) to gather during } \\
\text { wars }\end{array}$ & 363 & 3.0496 & 1.07855 \\
\hline Indyer was used for announcing the death of a prominent or illustrious son (Shagba Or or Shagba Wan) & 363 & 3.4766 & .84512 \\
\hline The Indyer was used in announcing the marriage of a prominent person in the society & 363 & 3.2259 & .90955 \\
\hline $\begin{array}{l}\text { The Indyer was used for announcing to the people that a beast (Inyamkyume) has devoured someone in the } \\
\text { jungle or somebody has been drawn mystically (i tsue or shin mnger) in the river or water }\end{array}$ & 363 & 2.8678 & .58445 \\
\hline Indyer was also used in announcing the Tiv Magic and Tiv Healing Ritual Convention (Akombo á Mirin) & 363 & 3.7080 & .62862 \\
\hline The Indyer was for inviting people to crucial meetings or social gatherings & 363 & 3.0275 & .83057 \\
\hline Valid N (listwise) & 363 & & \\
\hline
\end{tabular}

The result in Table 1 shows the mean rating scores of all the items above 2.50. This means respondents agreed that Areas Indyer was used as a means of communication among the Tiv People of Vandeikya Local Government Area of Benue State, Nigeria included wars (announcing the advancing of enemies and asking warriors (Anomaior) to gather), obituaries (for announcing the death of a prominent or illustrious son), marriage ceremonies (announcing the marriage of a prominent person in the society), disasters (announcing to the people that a beast has devoured someone in the jungle or somebody has been drawn mystically in the river or water), religious gatherings (announcing the Tiv
Magic and Tiv Healing Ritual Conventions) and social gatherings (inviting people to crucial meetings or social gatherings).

Research Question 2.

What are the effects of Indyer as a means of communication among the Tiv people of Vandeikya Local Government Area of Benue State?

To answer Research Question 2, data on effects of Indyer as a means of communication among the Tiv people of Vandeikya Local Government Area of Benue State, Nigeria were collected. The collected data were analyzed and presented in Table 2 .

Table 2. Descriptive Statistics of Effects of Indyer as a Means of Communication among the Tiv People of Vandeikya Local Government Area of Benue State, Nigeria.

\begin{tabular}{|c|c|c|c|}
\hline \multicolumn{4}{|l|}{ Descriptive Statistics } \\
\hline & $\mathbf{N}$ & Mean & Std. Deviation \\
\hline The beating of Indyer (Indyer $i$ tan) helped in awareness creation during wars & 363 & 2.8044 & .96787 \\
\hline $\begin{array}{l}\text { The People took announcements such as death of a prominent or illustrious son coming from the Indyer beats } \\
\text { seriously due to its affiliation to Tiv Indigenous Religion }\end{array}$ & 363 & 3.7052 & .65532 \\
\hline $\begin{array}{l}\text { The generosity in use of Indyer among the people enhanced peaceful and harmonious coexistence between } \\
\text { kindred and districts }\end{array}$ & 363 & 3.5234 & .85163 \\
\hline $\begin{array}{l}\text { The Indyer served as a medium of organizing the people to crucial social gatherings such as Imo (song) Amar } \\
\text { (dance) and Akombu (Healing Rituals) for the development of the communities }\end{array}$ & 363 & 3.7961 & .40342 \\
\hline Valid N (listwise) & 363 & & \\
\hline
\end{tabular}

From Table 2, it can be seen that the mean rating scores of all the items are above 2.50 , which means that the effects of Indyer as a mean of communication among the Tiv people of Vandeikya Local Government Area of Benue State is through awareness creation during wars, making people take information coming from the beating of Indyer serious, enhancing peaceful and harmonious coexistence between kindred and districts and organization of people to crucial social and religious gatherings for the development of the communities.

\subsection{Research Question 3}

What are the challenges affecting Indyer as a means of communication among the Tiv people of Vandeikya Local Government Area of Benue State? 
To answer Research Question 3, data were collected on challenges of Indyer as a means of communication among the Tiv people of Vandeikya Local Government Area of Benue State, Nigeria, analyzed and presented in Table 3.

Table 3. Descriptive Statistics of Challenges of Indyer as a Means of Communication among the Tiv People of Vandeikya Local Government Area of Benue State, Nigeria.

\begin{tabular}{|c|c|c|c|}
\hline \multicolumn{4}{|l|}{ Descriptive Statistics } \\
\hline & $\mathbf{N}$ & Mean & Std. Deviation \\
\hline $\begin{array}{l}\text { The beliefs that Indyer is not ordinarily constructed or sounded (beaten) makes the Christian converts consider it } \\
\text { fetish as such been against Christian religion }\end{array}$ & 363 & 3.5510 & .49808 \\
\hline $\begin{array}{l}\text { The communication skills of the Indyer is limited to few people who can use it to communicate and interpret the } \\
\text { knowledge communicated }\end{array}$ & 363 & 3.4573 & .84436 \\
\hline $\begin{array}{l}\text { The qualification of acquiring Indyer is so high that so many communities do not have one person who is worthy to } \\
\text { own it }\end{array}$ & 363 & 3.1873 & .92429 \\
\hline $\begin{array}{l}\text { The advent of Intellectual Property Laws such as The Paris Convention and the Agreement on Trade-Related } \\
\text { Aspects of Intellectual Property (TRIPs) have prevented the development of Indyer as a means of communication } \\
\text { among the Tiv of Vandeikya }\end{array}$ & 363 & 2.7190 & .74947 \\
\hline $\begin{array}{l}\text { The advent of western telecommunication in Nigeria in } 1886 \text { and GSM (Global System of Mobile Communication) } \\
\text { in } 1999 \text { posed a challenge to the Indyer as a means of communication among the Tiv of Vandeikya }\end{array}$ & 363 & 3.3499 & 1.03871 \\
\hline The destruction of Tiv cultural heritage including the Indyer by Colonialism & 363 & 2.9063 & .87762 \\
\hline Valid N (listwise) & 363 & & \\
\hline
\end{tabular}

From Table 3, it can be seen that the mean rating scores of all the items are above 2.50, which implies that the beliefs that Indyer is not ordinarily constructed or sounded (beaten) makes the Christian converts consider it fetish as such been against Christian religion, the communication skills of the Indyer is limited to few people who can use it to communicate and interpret the knowledge communicated, the qualification of acquiring Indyer is so high that so many communities do not have one person who is worthy to own it, the advent of Intellectual Property Laws such as The Paris Convention and the Agreement on Trade-Related Aspects of Intellectual Property (TRIPs) have prevented the development of Indyer as a means of communication among the Tiv of Vandeikya, the advent of western telecommunication in Nigeria in 1886 and GSM (Global System of Mobile Communication) in 1999 posed a challenge to the Indyer as a means of communication among the Tiv of Vandeikya and the destruction of Tiv cultural heritage including the Indyer by Colonialism are the challenges affecting Indyer as a means of communication among the Tiv people of Vandeikya Local
Government Area of Benue State.

\subsection{Research Hypotheses}

Hypotheses were formulated to test the significances if there are in the study, in the study area. The hypotheses were tested at 0.05 level of significance. Since Statistical Package for Social Sciences (SPSS) was used for this analysis, the 0.05 is compared with Asymp. Sig (computer calculated probability for decision taking) value denoted as $\mathrm{P}$. Therefore, if $\mathrm{P}$ was greater than 0.05 the hypothesis was not rejected.

Hypotheses 1.

There are no significant effects of Indyer as a means of communication among the Tiv people of Vandeikya Local Government Area of Benue State, Nigeria.

To test for Hypothesis 1, data were collected relating to effects of Indyer as a means of communication among the Tiv people of Vandeikya Local Government Area of Benue State, Nigeria, analyzed and presented in Table 4.

Table 4. Chi-Square Test of Opinion of Respondents on Effects of Indyer as a Means of Communication among the Tiv People of Vandeikya Local Government Area of Benue State, Nigeria.

\begin{tabular}{|c|c|c|c|c|c|c|}
\hline & Observed $\mathbf{N}$ & Expected N & $x^{2}$ & df & Asymp. Sig & Remarks \\
\hline $\begin{array}{l}\text { There are no significant effects of Indyer as a means of } \\
\text { communication among the Tiv people of Vandeikya }\end{array}$ & 2 & 181.5 & 355.044 & 1 & .000 & Significant \\
\hline $\begin{array}{l}\text { There are significant effects of Indyer as a means of } \\
\text { communication among the Tiv people of Vandeikya }\end{array}$ & 361 & 181.5 & & & & \\
\hline Total & 363 & & & & & \\
\hline
\end{tabular}

From Table 4, it can be seen that 2 with expected frequency of 181.5 respondents were of the opinion that there are no significant effects of Indyer as a means of communication among the Tiv people of Vandeikya while 361 with expected frequency of 181.5 respondents have disagreed that there are significant effects of Indyer as a means of communication among the Tiv people of
Vandeikya. Testing for the difference, $\chi^{2}=355.044$ with $\mathrm{df}=$ 1 and had computer calculated probability for decision taking (Asymp. Sig.) $=.000=$ P. Since $\mathrm{P}$ is less than 0.05 (significance level) then the difference is statistically significant. The hypothesis is therefore rejected with the conclusion that there are significant effects of Indyer as a means of communication among the Tiv people of Vandeikya 
Local Government Area of Benue State, Nigeria.

\subsection{Hypotheses 2}

There are no significant challenges affecting Indyer as a means of communication among the Tiv people of Vandeikya Local Government Area of Benue State, Nigeria
In order to test for Hypothesis 2, data were collected relating to challenges of Indyer as a means of communication among the Tiv people of Vandeikya Local Government Area of Benue State, Nigeria. The collected data were analyzed and presented in Table 5.

Table 5. Chi-Square Test of Opinion of Respondents on Challenges of Indyer as a Means of Communication among the Tiv People of Vandeikya Local Government Area of Benue State, Nigeria.

\begin{tabular}{|c|c|c|c|c|c|c|}
\hline & Observed N & Expected N & $x^{2}$ & df & Asymp. Sig & Remarks \\
\hline $\begin{array}{l}\text { There are no significant challenges affecting Indyer as a means of } \\
\text { communication among the Tiv people of Vandeikya }\end{array}$ & 32 & 181.5 & 246.284 & 1 & .000 & Significant \\
\hline $\begin{array}{l}\text { There are significant challenges affecting Indyer as a means of } \\
\text { communication among the Tiv people of Vandeikya }\end{array}$ & 331 & 181.5 & & & & \\
\hline Total & 363 & & & & & \\
\hline
\end{tabular}

Table 5 shows 32 with expected frequency of 181.5 respondents who were of the opinion that there are no significant challenges affecting Indyer as a means of communication among the Tiv people of Vandeikya while 331 with expected frequency of 181.5 respondents were of the opinion that there are significant challenges affecting Indyer as a means of communication among the Tiv people of Vandeikya. Testing for the difference, $\chi^{2}=246.284$ with $\mathrm{df}$ $=1$ and had computer calculated probability for decision taking (Asymp. Sig.) $=.000=$ P. Since P is less than 0.05 (significance level), the difference is statistically significant. Therefore, the hypothesis is rejected with the conclusion that there are significant challenges affecting Indyer as a means of communication among the Tiv people of Vandeikya Local Government Area of Benue State, Nigeria.

\section{Discussion of Findings}

1. Based on the results in Table 1, the findings from the study showed that announcing the advancing of enemies and asking warriors (Anomaior) to gather during wars, announcement of obituaries, marriage ceremonies, disasters and announcement of religious and social gatherings were areas Indyer was used as a mean of communication among the Tiv people of Vandeikya Local Government Area of Benue State, Nigeria. This is in line with Ahamefula, Okoye, Onwuegbuchunam and Uzoigwe (2014) who believe that in the Tiv culture, Indyer instrument can be to announce deaths or vital events in Tiv culture. The sounds produced communicate a particular meaning tied to a particular event such as death.

2. Moreover, based on the results in Table 2, the study revealed that there are effects of Indyer as a mean of communication among the Tiv people of Vandeikya Local Government Area of Benue State, Nigeria including awareness creation during wars, making people take information coming from the beating of Indyer serious, enhancing peaceful and harmonious coexistence between kindred and districts and organization of people to crucial social and religious gatherings for the development of the communities. The hypothesis was rejected with the conclusion that there are significant effects of Indyer as a means of communication among the Tiv people of Vandeikya Local Government Area of Benue State, Nigeria.

3. Consequently, based on the results in Table 3 , the study showed that the beliefs that Indyer is not ordinarily constructed or sounded (beaten) makes the Christian converts consider it fetish as such been against Christian religion, the communication skills of the Indyer is limited to few people who can use it to communicate and interpret the knowledge communicated, the qualification of acquiring Indyer is so high that so many communities do not have one person who is worthy to own it, the advent of Intellectual Property Laws such as The Paris Convention and the Agreement on Trade-Related Aspects of Intellectual Property (TRIPs) have prevented the development of Indyer as a means of communication among the Tiv of Vandeikya, the advent of western telecommunication in Nigeria in 1886 and GSM (Global System of Mobile Communication) in 1999 posed a challenge to the Indyer as a means of communication among the Tiv of Vandeikya and the destruction of Tiv cultural heritage including the Indyer by Colonialism are the challenges affecting Indyer as a means of communication among the Tiv people of Vandeikya Local Government Area of Benue State. The hypothesis was rejected with the conclusion that there are significant challenges affecting Indyer as a means of communication among the Tiv people of Vandeikya Local Government Area of Benue State, Nigeria.

\section{Recommendations}

The research finding discovered that the Indyer has significant effect as a mean of communication among the Tiv people of Vandeikya Local Government Area of Benue State, Nigeria however, there are potential challenges affecting it. Therefore, it was recommended that the Federal Government of Nigeria should discard the International Intellectual Property Laws such as The Paris Convention and the 
Agreement on Trade-Related Aspects of Intellectual Property (TRIPs) and develop its IP laws to be in conformity with indigenous practices and what is obtainable in the Nigerian folds and Christian converts and leaders should accept Indyer as a technological device not a fetish component.

\section{Conclusion}

This study, the effects of Indyer as a mean of communication among the Tiv people of Vandeikya Local Government Area of Benue State, Nigeria was carried out in Vandeikya. The study found that Indyer was used in announcing the advancing of enemies and asking warriors to gather during wars, announcement of obituaries, marriage ceremonies, disasters and announcement of religious and social gatherings. Essentially, the study concludes that Indyer has significant effects as a means of communication among the Tiv people of Vandeikya but also that it has potential challenges militating against it. Since the use of Indyer has proved to be a significant means of communication among the Tiv people of Vandeikya, the Tiv traditional council, local and state governments as well as other stakeholders in general should do everything possible to encourage the development of this quite important indigenous technological device to metamorphose into the next level Tiv indigenous technology for the scienctific and technological development of the Tiv nation, Benue state, Nigeria and Africa at large as well as posterity.

\section{References}

[1] Agber, T. C. \& Mase, I. E. (2014). Tiv types and methods of fishing in Vandeikya local government area. Retrieved from https://www.academia.edu/8545047/Tiv_Types_and_Methods _of_Fishing_In_Vandeikya_Local_Government_Area.

[2] Agber, T. C., Udu, T. T., Fiase, G. A. \& Aniho, T. T. (2015). Tiv traditional religion and its contribution to the tradoeducational and technological development of the Tiv society. Humanities and Social Sciences, 3 (5), 215-224.

[3] Agber, T. C., Ugbagir, N. N., Mngutyô, J. N. and Amaakaven, F. G. (2014). Acquisition of audiovisual materials on the Tiv Tyumbun magic rite by the public libraries in Benue State of Nigeria. LIBRI, 64 (4), 408-419.

[4] Agera, S. I. N., Adegeye, A. O. \& Jimoh S. O. (2009). Deforestation trends in forest estates of Vandeikya local government, Benue state, Nigeria. Journal of Research in Forestry, Wildlife and Environment, (1), 46-55.

[5] Ahamefula, N. O., Okoye, C. L., Onwuegbuchunam, M. O. \& Uzoigwe, B. C. (2014). Preliminary study on the use of sound and acoustics in Igbo cultural communication. Innovare Journal of Social Sciences, 2 (3), 35-39.

[6] Ashalatha, D. (2015). Concept of communication. New Delhi: Sri Venkateswara College of Engineering and Technology Press.

[7] Ayirebasia, A. (2008). The Role of Indigenous Modes of
Communication in Enhancing Development Support Communication in Ghana (Unpublished Master's Thesis). University for Development, UDS, Tamale.

[8] Ayirebasia, A. (2008). The Role of indigenous modes of communication in enhancing development support communication in Ghana (Unpublished Master Thesis). University for Development, Tamale.

[9] Beltran, L. R. (1974). Rural Development and Social Communication: Relationship and Strategies. Cornell, CIAT International Symposium on Communication Strategies for Rural Development. New York: Cornell University Institute for International Agriculture.

[10] Diaz-Bordenave, J. E. (1979). Handbook of intercultural communication. New York: Sage Publications.

[11] Emaikwu, S. O. (2015). Fundamentals of research methods and statistics. (Rev. Ed.). Makurdi: Selfers Academic Press Limited.

[12] Finnegan, R. (1997). Oral literature in Africa. London: Oxford University Press.

[13] Freire, P. (1985). The Politics of education: Culture, power and liberation. London: Macmillan.

[14] Gbenda, J. S. (2005). Eschatology in Tiv traditional Religious Culture: An interpretive inquiry. Nsukka: Chuka Educational Publishers.

[15] Hoffmann, V., (2000), Picture Supported Communication in Africa. Fundamentals, examples and recommendations for appropriate communication processes in rural development programmes in sub-Saharan Africa. Weikersheim- Germany: Margraf Publishers.

[16] Mundy, P. \& Compton, J. L. (1991). Indigenous communication and indigenous knowledge. Development Communication Report 74. Clearinghouse on Development Communication, Arlington, VA.

[17] National Population Commission, (2009). 2006 population and housing census of the federal republic of Nigeria. Benue State priority tables (volume I). Abuja: National Population Commission Press.

[18] Nketia, J. H. K. (1963). Drumming in Akan Communities of Ghana. Edinburgh: Thomas Nelson.

[19] Ushe M. U. (2010). The Mortgage Culture of Tiv Death and Burial Rites. Lagos: Vast Publishers.

[20] Ushe, M. N (2005). Between Continuity and change: A Comparism of Tiv and Christian's concept of Death and Burial Rites (Unpublished Doctorate Dissertation). University of Jos.

[21] Ushe, M. N. (2007). Kpor of Tiv culture. Enugu: Sam Press.

[22] Ushe, M. U. (2015). The Talking Drum: An Inquiry into the reach of a traditional mode of communication. International Journal of Philosophy and Theology, 3 (1), 110-117.

[23] Wang, G. \& Dissanayake, W. (Eds.) (1984). Continuity and change in communication systems: an Asian perspective. Norwood - NJ: Ablex

[24] Wikipedia, (2014). Vandeikya. Retrieved from http://en.wikipedia.org/wiki/Vandeikya. 